\title{
SLOVENSKÉ A POLSKÉ LINGVISTICKÉ TERMÍNY Z ASPEKTU TEMPORÁLNEJ MOTIVÁCIE ${ }^{1}$
}

\section{Slovak and Polish Linguistic Terms in the View of Temporal Motivation}

Keywords: Slovak language, Polish language, linguistic terms, temporal motivation

Contact: Prešovská univerzita v Prešove; fatulova.dominika@gmail.com

\section{1 Úvod}

Lingvistická terminológia je súborom pomenovaní jednotlivých javov voblasti jazykovedy. Jazykovedná terminológia tvorí jednu zo základných zložiek lingvistiky a zohráva významnú úlohu pri štúdiu materinského či cudzieho jazyka. Rovnako ako v terminológii iných vedných odborov (medicína, chémia, informatika), aj v jazykovednej terminológii sa stretávame so zastarávaním jednotlivých lexém a ich plynulým prechodom do periférie lexikálnej zásoby a zároveň s obohacovaním jazykovednej terminologickej sústavy prostredníctvom vzniku nových termínov, ako odraz rozvoja lingvistiky a formovania nových smerov lingvistického výskumu a nových lingvistických disciplín. Z tohto dôvodu sme sa rozhodli venovat' pozornost' práve časovo príznakovým lexémam v slovenskej a pol'skej jazykovednej terminológii, ktoré opíšeme a porovnáme na základe vybraného typu lexikálnej motivácie temporálnej motivácie. Budeme vychádzat’ z prvotnej typológie lexikálnej motivácie a pojmovo-terminologického vymedzenia jednotlivých motivačných typov J. Furdíka (2008), a viacerých prác M. Ološtiaka (2011, 2015, 2018), ktorý túto teóriu rozvinul.

\section{Temporálna motivácia}

Teóriu lexikálnej motivácie rozpracoval J. Furdík (2008), v ktorej predstavil svoju koncepciu možných prístupov k skúmaniu lexikálnej zásoby. V tejto koncepcii sa lexika považuje za súbor lexém (jednoslovných i viacslovných), ktoré sú navzájom späté siet’ami rôznych vzt’ahov. Motivatológ J. Furdík vymedzil 17 typov lexikálnej motivácie (2008: 33). Všetky typy motivácie sú dynamické a pohyblivé, lexikálne jednotky ich

\footnotetext{
${ }^{1}$ Táto práca bola podporená Agentúrou na podporu výskumu a vývoja na základe Zmluvy č. APVV-18-0046.
} 
môžu nadobúdat' i strácat'. Na jeho prácu nadviazal M. Ološtiak, ktorý teóriu lexikálnej motivácie značne rozvinul vo viacerých prácach $(2011,2015,2018)$. Podobne ako jeho predchodca, aj M. Ološtiak prezentuje rovnaký počet motivačných typov. Jednotlivé typy sú rozdelené na základné, kontaktové a nadstavbové (pragmatické) typy, medzi ktoré patrí aj temporálna motivácii, ktorej sa venujeme v tomto príspevku.

Za temporálne motivované sa považujú časovo príznakové lexikálne jednotky. Na jednej strane sú to „lexikálni seniori“ (najmä archaizmy a historizmy), na druhej strane „lexikálni juniori“ (neologizmy). Temporálne motivované lexémy možno nájst' aj v lingvistickej terminológii. Slovenská a pol'ská jazykoveda sa vyvíjala niekol’ko storočí, s čím je prirodzene spojený aj zánik niektorých lingvistických javov a zároveň aj ich pomenovaní (termínov), ide o tzv. terminologické historizmy. Popri nich stoja tzv. terminologické archaizmy, teda lingvistické termíny, ktoré boli nahradené novšími pomenovaniami, a s ktorými vstupujú do synonymických vzt’ahov. S neustálym rozvojom jazykovedy je spojený aj vznik nových lingvistických termínov, ktorými sa obohacuje odborná jazykovedná terminológia. Neologizmy v jazykovednej terminológii bud' pomenúvajú úplne nový denotát (analógia s historizmami), alebo ide o potrebu štylistického obohatenia terminologickej sústavy (analógia s archaizmami). Konkrétne príklady časovo príznakových lexém v slovenskej a pol'skej lingvistickej terminológii predstavíme $\mathrm{v}$ dvoch nasledujúcich kapitolách.

\section{Archaizmy a historizmy v slovenskej a pol'skej lingvistickej terminológii}

V lexikálnej zásobe každého jazyka dochádza $\mathrm{k}$ nahrádzaniu jednotlivých pomenovaní novšími lexémami a výnimkou nie je ani lexika terminologických sústav rôznych odborov. Tak isto aj v jazykovednej terminológii sa môžno stretnút' s javom, kedy sa staršie pomenovania jednotlivých denotátov nahrádzajú novšími lexémami. Dochádza tak k vzniku archaizmov v jazykovednej terminológii. Jednotlivé staršie termíny sú tak v priebehu vývinu lingvistiky „vytláčané“ novšími termínmi na perifériu jazykovednej terminológie. Samotný proces presunu termínov „do pasívnej lexikálnej zásoby v spojitosti s ich zastarávaním je spravidla dlhodobí proces“ (Dolník 2003: 191).

V slovenskej jazykovednej terminológii možno sledovat' zmeny v pomenovaniach jednotlivých lingvistických disciplín, napr. archaizmus vetoslovie I súčasné termíny syntax / skladba, archaizmus jazykospyt / súčasné termíny jazykověda / lingvistika, archaizmus významoslovie / súčasný termín sémantika, archaizmus kmeňoslovie / súčasný termín slovotvorba. Terminologické archaizmy sa vyskytujú aj $\mathrm{v}$ rámci jednotlivých jazykových rovín, napr. v ortografii archaizmus strednik / semikolón / súčasný termín bodkočiarka, archaizmus bod / súčasný termín bodka; 
v dialektológii archaizmus podrečie / súčasné termíny nárečie / dialekt; v lexikografii archaizmus vokabulár / súčasný termín slovník, v morfológii archaizmus časti reči / súčasný termín slovné druhy.

Zmeny v pomenovaniach konkrétnych denotátov možno sledovat' aj v pol'skej jazykovednej terminológii, napr. archaizmus abecadło / súčasný termín alfabet, archaizmus głosownia / súčasný termín fonetyka, archaizmus słowo / súčasný termín czasownik, archaizmus wokabularz / súčasný termín słownik.

Medzi časovo deaktualizované lexémy patria aj historizmy, pre ktoré je charakteristický zánik denotátu a pojmu a ich prostredníctvom sa „v pamäti jazykového spoločenstva zachovali v kondenzovanej podobe znalosti o historických objektoch.“ (Dolník 2003: 190). Na rozdiel od archaizmov nemajú svoj neutrálny náprotivok (porov. historizmus duál / dvojné číslo - Ø a archaizmus vokabulár - slovník).

S historizmami sa možno stretnút' aj v lingvistickej terminológii, ked’že s vývojom jazyka je spätý aj zánik jednotlivých lingvistických javov s čím súvisí aj zánik lingvistických termínov, teda ak pominie denotát, vytratí sa aj jeho pomenovanie.

Medzi historizmy v slovenskej a pol'skej lingvistickej terminológii môžeme zaradit' napr. termín slov. duál/dvojné číslo, pol'. dualis/liczba podwójna. Ide o pomenovanie gramatickej kategórie, podl'a ktorej sa skloňovali substantíva nachádzajúce sa v počte dva. Zanikla v 13.-14. storočí v takmer všetkých slovanských jazykoch (vrátane slovenčiny a pol’štiny). V slovenčine a v pol'štine sa po nej zachovalo len niekol'ko tvarov vo funkcii plurálu (napr. slov. dvoma, očú; pol'. ręce, oczy).

Porovnaním slovenskej a pol'skej sústavy pádov môžeme pozorovat' výrazný rozdiel v počte jednotlivých komponentov (v slovenčine 6 pádov, v pol’štine 7 pádov). V súčasnej slovenčine absentuje zaniknutý pád vokatív ${ }^{2}$, ktorého funkcie v spisovnom jazyku prevzal nominatív. Na rozdiel od slovenčiny, v spisovnej pol’štine sa dodnes zachoval ako siedmy pád - wołacz.

\section{Neologizmy v slovenskej a pol'skej lingvistickej terminológii}

Lingvistická terminológia, podobne ako terminológia iných vedných odborov, sa neustále vyvíja, najmä v posledných desat'ročiach zaznamenala intenzívny rozvoj. Vznikajú nové pomedzné disciplíny (napr. sociolingvistika, psycholingvistika, lingvokulturológia) a stým súvisí aj vznik nových prístupov, metód a smerov lingvistického výskumu (napr. korpusová lingvistika), ako aj nových termínov

\footnotetext{
${ }^{2}$ V slovenčine sa vokatív zachoval v náboženskom štýle (napr. Otče, Bože) a v niektorých nárečiach (napr. v šarišskom nárečí), no jeho stopy možno vidiet' aj v spisovnom jazyku (napr. pane, chlapče, sy(n)ku).
} 
(terminologických neologizmov), ktoré je potrebné zaznamenat'. S týmto vývojom je spojená aj zvýšená terminotvorba v slovenskej a pol’skej jazykovede. „Nové termíny sa tvoria podl'a terminologickej potreby a stupňa vedeckého poznania, pričom každý novoutvorený termín možno pokladat' za terminologický neologizmus“ (Ološtiak 2015: 76).

Jednou z dynamicky sa rozvíjajúcich oblastí v slovenskej a pol'skej jazykovede je korpusová lingvistika, ktorá skúma a opisuje jazyk a jeho použitie v konkrétnych textoch, ktoré sa vyhl'adávajú v korpuse. Vd’aka tomuto rozvoju sa slovenská a pol'ská lingvistická terminológia obohacuje o nové termíny, ktoré sa postupne stávajú súčast'ou odbornej terminológie a po čase sa stratí ich príznak novosti. Slovenská a pol'ská jazykovedná terminologická sústava sa tak obohatila o nové termíny z oblasti korpusovej lingvistiky, napr. slov. korpus, národný korpus, paralelný korpus, synchrónny korpus, podkorpus, lema, lematizácia, lematizátor, kolokácia, tag, tager, tagovanie, tagset, token, tokenizácia, výskyt, počítačové spracovanie prirodzeného jazyka, segmentácia, korpusová gramatika a i.; pol'. korpus, podkorpus, korpus języka mówionego, lemat, lematyzacja, tagowanie, konkordancja, indeksowanie, kolokacja, kolokat, kolokator, segment, segmentacja tekstu, anotacja, adnotacja a i.

Približne v 90. rokoch minulého storočia sa začala intenzívne rozvíjat' lingvokulturologická metodológia, ktorá sa využíva zvlášt’ v rusitike. Na túto metodológiu nadviazali aj slovenskí filológovia - rusisti (napr. na PU v Prešove sa lingvokulturologické výskumy zintenzívnili v rámci Lingvokulturologického a prekladatel'sko-tlmočníckeho Centra excelentnosti), pričom terminologicky vychádzajú z termínov, napr. lingvokulturéma, koncept, konceptosféra, precedentné fenomény, precedentné mená, jazykový obraz sveta, historické lingvokulturémy, literárne lingvokulturémy, antické historické precedensy, puškinizmus a i., ktoré zároveň možno považovat' za terminologické neologizmy. Na lingvokulturológiu nadväzujú aj d’alšie filologické odbory, ktoré so sebou prinášajú novú lingvistickú terminológiu, napr. politická lingvistika - putinizmus, sovietizmus, mečiarizmus a i.

Pri komparatívnom výskume príbuzných jazykov (ako sú napr. slovenčina a pol’ština) sa možno stretnút' so situáciou, kedy v jednom z jazykov absentuje odborný termín, hoci samotný denotát je prítomný v oboch jazykoch. Jazyk s chýbajúcim pomenovaním sa môže obohatit' o nový termín prostredníctvom prevzatia $\mathrm{z}$ druhého jazyka, v ktorom je tento termín zaužívaný. Ako príklad môžeme uviest' slovenské jazykovedné termíny, neznáme pre pol'skú jazykovedu, ktoré pomenúvajú prechody medzi slovnými druhmi. Dvojslovné termíny, v ktorých prvá čast' (prefix de-) označuje motivant a druhá čast' (sufix -izácia) poukazuje na motivát, napr. termíny deprepozicionálna partikulizácia, deprepozicionálna adverbializácia, desubstantívna 
prepozicionalizácia a i. M. Vojteková aplikovala do pol'ského jazyka jako deprepozycjonalna partykulizacja, deprepozycjonalna adwerbializacja, desubstantywna prepozycjonalizacja (Vojteková 2018b: 80, 81, 82). Takéto terminologické neologizmy môžu v jazyku po istom čase zaniknút', alebo sa stat' súčast'ou odbornej terminológie.

\section{Záver}

V jazykovednej terminológii sa možno stretnút's temporálne motivovanými lexémami. Za temporálne motivované sa považujú časovo príznakové lexikálne jednotky. Na jednej strane sú to „lexikálni seniori“ (najmä archaizmy a historizmy), na druhej strane „lexikálni juniori“ (neologizmy). V lingvistickej terminológii sa stretávame s javom, kedy sa staršie pomenovania jednotlivých denotátov nahrádzajú novšími lexémami. Dochádza tak k vzniku archaizmov v jazykovednej terminológii (napr. slov. archaizmus významoslovie / súčasný termín sémantika; pol'. abecadło / súčasný termín alfabet). $\mathrm{S}$ vývojom jazyka je spätý aj zánik jednotlivých lingvistických javov s čím súvisí aj presun lingvistických termínov, ktoré sa s postupom času dostávajú na perifériu lexikálnej zásoby jako tzv, terminologické historizmy (napr. slov. duál / dvojné číslo; pol'. dualis / liczba podwójna). Medzi temporálne motivované patria aj terminologické neologizmy, ktoré sú odrazom dynamického rozvoja lingvistiky, vzniku nových lingvistických disciplín a nových smerov lingvistického výskumu. V posledných desat'ročiach sa rozvinula korpusová lingvistika, vd'aka ktorej sa do slovenskej a pol'skej jazykovednej terminológie dostali nové termíny (napr. slov. lema, tagovanie; pol'. indeksowanie, podkorpus). V slovenskom jazykovednom prostredí sa začala intenzívne rozvíjat' lingvokulturológia, pomocou ktorej sa do slovenskej jazykovedy zaviedli nové termíny (napr. lingvokulturéma, precedentné fenomény, puškinizmus). Niekedy sa môže jazyk obohatit' o nový termín prostredníctvom prevzatia z druhého jazyka, v ktorom je tento termín zaužívaný (napr. slov. deprepozicionálna partikulizácia $\rightarrow$ deprepozycjonalna partykulizacja). Terminologické neologizmy s postupom času strácajú príznak novosti a stávajú sa plnohodnotnou súčast'ou terminologickej sústavy.

\section{Summary}

The paper describes Slovak and Polish linguistic terms as terminologically motivated units from the perspective of selected lexical motivation type - temporal motivation. Temporal motivation is a result of the temporal principle in language. Time also intrinsically touches language units - their birth, adolescence, productive age, retirement age and extinction. Temporal motivation refers to two lexical groups: a) obsolete, old- 
fashioned words (archaisms, historicisms); b) new words (neologisms), which also appear in Slovak and Polish linguistic terminology. The paper is based on the theory of lexival motivation, the primary typology of lexical motivation and notionalterminological specification of particular motivation types by J. Furdík (2008) as well as on various publications by M. Ološtiak who has significantly developed theory of lexical motivation.

\section{Literatúra}

Dolník, J. Lexikológia. Bratislava: Univerzita Komenského, 2003.

Dubisz, S. (ed.) Uniwersalny słownik języka polskiego. Warszawa: Wydawnictwo Naukowe PWN, 2003.

Furdík, J. Teória motivácie v lexikálnej zásobe. Ološtiak, M. (ed.) Košice: Vydavatel'stvo LG, 2008.

Gałąb, Z., Heinz, A., Polański, K. Stownik terminologii językoznawczej. Warszawa: Państwowe Wydawnictwo Naukowe, 1970.

Gianitsová-Ološtiaková, L., Ološtiak, M., Rešovská, S. Slovotvorná motivácia a temporálna motivácia. In: Ološtiak, M. (ed.) Kvalitatívne a kvantitatívne aspekty tvorenia slov v slovenčine. Prešov: Filozofická fakulta Prešovskej univerzity v Prešove, 2015, s. 830-908.

Gruszczyński, W., Bralczyk, J. Słownik gramatyki języka polskiego. Warszawa: Wydawnictwa Szkolne i Pedagogiczne Spółka Akcyjna, 2002.

Horecký, J., Rácová, A. Slovnik jazykovedných termínov. Bratislava: Slovenské pedagogické nakladatel'stvo, 1979.

Horecký, J., Buzássyová, K., Bosák, J. et al. Dynamika slovnej zásoby súčasnej slovenčiny. Bratislava: VEDA, vydavatel'stvo Slovenskej akadémie vied, 1989.

Mistrík, J. (ed.) Encyklopédia jazykovedy. Bratislava: Obzor, 1993.

Mistrík, J. Lingvistický slovnik. Bratislava: Slovenské pedagogické nakladatel'stvo, 2002.

Ološtiak, M. Aspekty teórie lexikálnej motivácie. Prešov: Filozofická fakulta Prešovskej univerzity v Prešove, 2011.

Ološtiak, M. O terminologickej motivácii v lexike. In: Mislovičová, S. (ed.) Jazyková kultúra a terminológia: zborník štúdií venovaný Matejovi Považajovi. Bratislava: VEDA, vydavatel'stvo Slovenskej akadémie vied, 2015, s. 54-82. 
Ološtiak, M., Gianitsová-Ološtiaková, L. Neologizmy a neologizácia z pohl'adu teórie lexikálnej motivácie. In: Hradilová, D. (ed.) Inovační procesy v češtine a jí blizcích jazycích. Olomouc: UPOL, 2018, s. 9-40.

Oravec, J., Bajzíková, E., Furdík, J. Súčasný slovenský spisovný jazyk. Morfológia. Bratislava: Slovenské pedagogické nakladatel'stvo, 1984.

Pisarčíková, M. (ed.) Synonymický slovník slovenčiny. Bratislava: VEDA, 2004.

Peciar, Š. Základná jazykovedná terminológia. Bratislava: Slovenská akadémia vied a umení, 1952.

Podlawska, D., Płóciennik, I. Leksykon nauki o języku. Bielsko-Biała: Park, 2002.

Polański, K. (ed.) Encyklopedia językoznawstwa ogólnego. Wrocław-WarszawaKraków: Ossolineum, 2003.

Ružička, J. (ed.) Morfológia slovenského jazyka. Bratislava: Vydavatel'stvo Slovenskej akadémie vied, 1966.

Sipko, J. Lingvokulturológia našej doby. Prešov: Vydavatel'stvo Prešovskej univerzity, 2017.

Skarżyński, M. Stownik przypomnień gramatycznych dla studentów filologii polskiej. Kraków: Księgarnia Akademicka, 2000.

Szulc, A. Podręczny słownik językoznawca stosowanego. Warszawa: Państwowe Wydawnictwo Naukowe, 1984.

Šimková, M., Levická, J., Debnár, M. Dynamické javy v súčasnej slovenčine a jej výskume. Bratislava: VEDA, vydavatel'stvo Slovenskej akadémie vied, 2018.

Urbańczyk, S., Kucała, M. Encyklopedia języka polskiego. Wrocław-WarszawaKraków: Ossolineum, 1999.

Vojteková, M. (ed.) Jazykovedná terminológia v slovanskom kontexte. Prešov: Filozofická fakulta Prešovskej univerzity v Prešove, 2018 a.

Vojteková, M. Przyimek jako wyraz motywujący i motywowany w procesie motywacji morfologicznej. In: Mociołek, M. (ed.) Polonistyka na początku XXI wieku. Diagnozy, koncepcje, perspektywy. Tom III - Współczesne aspekty badań nad językiem polskim - teoria i praktyka. Katowice: Wydawnictwo Uniwersytetu Śląskiego, 2018b, s. 77-92.

Vojteková, M. Slovenské a pol'ské jazykovedné termíny z aspektu vybraných typov lexikálnej motivácie. In: Vojteková, M. (ed.) Jazykovedná terminológia 
v slovanskom kontexte. Prešov: Filozofická fakulta Prešovskej univerzity v Prešove, 2018, s. 7-37.

Żmigrodzki, P. (ed.) Wielki słownik języka polskiego. Dostupné z: https://www.wsjp.pl/ (2020-04-20).

(cc) $\$$ The article is accessible in open access mode under licence CC BY-NC-ND BY NC ND Creative Commons Attribution-NonCommercial-NoDerivatives 4.0 